\title{
ARCHIVES IN STRATEGIC DECISION-MAKING (A CASE STUDY AT THE FACULTY OF COMMUNICATION SCIENCE UNIVERSITAS PADJAJARAN)
}

\author{
Encang Saepudin*, Fadhilah Muhammad*, \& Sukaesih* \\ *Program Studi Ilmu Perpustakaan Fakultas Ilmu Komunikasi Universitas Padjadjaran \\ Email: encang@unpad.ac.id, fadhilahm1997@gmail.com, sukaesih@unpad.ac.id
}

\section{(Submitted: 07-11-2019, Revised: 21-10-2020, Accepted: 16-11-2020)}

DOI: $10.24252 /$ kah.v8i2a1

\begin{abstract}
ABSTRAK: Arsip dapat berperan sebagai data sebagai dasar pertimbangan, pengetahuan, pemikiran, dan penetapan keputusan. Penelitian ini bertujuan untuk mengetahui pemanfaatan arsip dalam pengambilan keputusan strategis. Penelitian ini menggunakan metode kualitatif dengan pendekatan studi kasus. Data penelitian diperoleh melalui wawancara kepada 5 orang ( 3 orang pimpinan fakultas dan 2 orang arsiparis). Selain itu, data juga diperoleh melalui diskusi, observasi, dan studi pustaka. Uji Validitas dan reliabilitas melalui proses triangulasi data dan trianggulasi sumber. Analisis data secara deskriptif melalui tahapan reduksi data, penyajian data, dan penarikan kesimpulan. Hasil penelitian menunjukkan terdapat empat faktor yang memengaruhi pemanfaatan arsip dalam proses pengambilan keputusan oleh pimpinan yaitu tipe pengambilan keputusan, dasar pengambilan keputusan, keberadaan regulasi, dan budaya organisasi. Tipe pengambilan keputusan yang digunakan adalah keputusan tidak terprogram karena memiliki sifat baru dan tidak terstruktur. Dasar pengambilan keputusan adalah rasional. Hal ini berarti pengambilan keputusan didasarkan pada hal-hal yang bersifat pasti. Adanya regulasi yang bertolak belakang antara satu aturan dengan aturan lainnya. Selanjutnya adalah budaya yang berlaku, yang menyulitkan pimpinan untuk bisa melakukan manajemen perubahan. Kesimpulan penelitian bahwa arsip sudah digunakan sebagai dasar dalam pengambilan keputusan.
\end{abstract}

Kata kunci: Arsip; Pengambilan keputusan; Keputusan strategis

ABSTRACT: Archives could be as data as a basis for consideration, knowledge, thoughts, and decision making. This study aims to determine the use of archives in strategic decision making. This study uses a qualitative method with a case study approach. The data were obtained through interviews with 5 persons (3 faculty leaders and 2 archivists). The data were also obtained through discussion, observation, and literature study. Validity and reliability tests through the process of triangulation of data and triangulation of sources. The descriptive data analysis through the stages of data reduction, data presentation, and drawing conclusions. The study found that there were four factors that influenced the use of archives in the decisionmaking process by the leaders which were the type of decision making, the basis for decision making, the existence of regulations, and organizational culture. The type of decision making used is unprogrammed decisions because it has new and unstructured characteristics. The basis for decision making is rational. This means that decision making is based on certain things. There are regulations that contradict one rule with another. And the prevailing culture which makes difficult for leaders to to carry out change management. As conclusion, the archive has been used as a basis for decision making.

Keywords: Archives; Decision-making; Srategic decisions 


\section{PENDAHULUAN}

Setiap permasalah yang dihadapi baik secara individu maupun kelompok harus dicari dan dibangun cara untuk menyelesaikannya. Begitu pun di dalam mencapai tujuan sebuah organisai pasti menghadapi berbagai permasalahan. Oleh karena itu, dapat dinyatakan bahwa penetapan keputusan dilatarbelakangi oleh adanya masalah dalam mencapai tujuan bersama. Proses pengambilan keputusan merupakan suatu kegiatan yang berkaitan dengan pemilihan alternatif pemecahan masalah. Pada setiap pilihan harus disertai oleh pertimbangan tentang risiko yang terkandung dalam setiap alternatif (Eniyati, 2011). Dengan demikian setiap pengambil keputusan dapat mempertimbangkan alternatif tersebut secara matang dan seksama.

Proses penyusunan alternatif pemecahan suatu masalah tidak boleh disusun secara sembarangan. Mengingat penyusunan arlternatif pemecahan masalah harus disertai berbagai gambaran tentang risiko dari pilihan pemecahan masalah tersebut (Dhalimi, 2015). Dalam menyusun gambaran risiko diperlukan informasi yang akurat dan lengkap. Oleh karena itu, sumber utama dalam menyusun strategi pengambilan keputusan adalah informasi. Dalam hal ini, sehebat apapun seorang pimpinan dalam teknik pengambilan keputusan, apabila informasi yang digunakan tidak memadai maka keputusan akan kurang bermutu.

Sumber informasi yang paling tepat untuk menyusun berbagai alternatif pemecahan masalah dalam sebuah organisasi adalah arsip. Arsip merupakan hasil kegiatan administrasi yang memiliki informasi penting. Informasi yang terkandung di dalam sebuah arsip dapat dijadikan sebagai bahan bukti pertanggungjawaban dan sumber informasi utama bagi kepentingan organisasi. Menurut kamus Administrasi Kearsipan merupakan "suatu bentuk pekerjaan tata usaha yang berupa penyusunan dokumen-dokumen secara sistematis sehingga bilamana diperlukan lagi dokumen-dokumen itu dapat ditemukan secara cepat" (Sugiarto 2005). Hal ini sejalan dengan batasan arsip yang ada dalam Undang-Undang Nomor 43 Tahun 2009 Tentang Kearsipan yang disebutkan bahwa arsip merupakan "Rekaman kegiatan atau peristiwa dalam berbagai bentuk dan media sesuai dengan perkembangan teknologi informasi dan komunikasi yang dibuat dan diterima oleh lembaga negara, pemerintahan daerah, lembaga pendidikan, perusahaan, organisasi politik, organisasi kemasyarakatan dan perseorangan dalam pelaksanaan kehidupan bermasyarakat, berbangsa dan bernegara".

Berdasarkan hal itu, sebuah lembaga memiliki kewajiban untuk menyelenggarakan kearsipan. Tanpa adanya sebuah penyelenggaraan kearsipan maka sebuah instansi tidak dapat memenuhi dan menunjang proses kegiatan dari suatu lembaga. Selain itu, arsip memiliki peran dalam proses penyajian informasi bagi setiap level pimpinan dalam sebuah organisasi. Peran arsip bagi pemimpin disini adalah sebagai bahan pertimbangan atau sebagai dasar di dalam menetapkan kebijakan organisasi (Jumiyati, 2016). Oleh karena itu, di dalam penataan arsip diperlukan sebuah sistem tertentu agar arsip bisa dikelola dengan baik. Dengan demikian setiap informasi yang terkandung di dalam arsip dapat ditata secara lengkap, cepat, dan benar. Hal ini harus dilakukan agar arsip memiliki nilai guna yang tinggi. Dengan demikian, nilai arsip bisa sejalan dengan nilai informasi yakni ketelitian, ketepatan waktu, kelengkapan, keringkasan, dan kesesuaian.

Menindaklanjuti hal tersebut Universitas Padjadjaran sejak Juni 2013 telah mendirikan lembaga kearsipan perguruan tinggi (LKPT) dengan nama unit pelaksana teknis Kearsipan (selanjutnya disebut UPT). Unit pelaksana teknis ini secara resmi dikukuhkan dengan Keputusan Menteri Pendidikan dan Kebudayaan nomor 46 Tahun 2013 tertanggal Mei 2013. UPT Kearsipan mulai tercantum dalam struktur organisasi dan tata kelola Universitas Padjadjaran berdasarkan Peraturan Rektor nomor 70 Tahun 2015 tanggal 11 September 2015. Dalam upaya mendukung tertib arsip di lingkungan Universitas Padjadjaran, UPT Kearsipan Universitas Padjadjaran mulai melaksanakan program kerja utama yaitu pengembangan sumber daya manusia melalui diklat ahli dan terampil. Pengembangan sumber daya manusia melalui pendidikan dan pelatihan ini bekerja sama dengan Pusdiklat Arsip Nasional. Pada Tahun 2014 UPT Kearsipan Universitas Padjadjaran mulai melaksanakan diklat untuk arsiparis kategori keahlian diikuti oleh 36 peserta dari berbagai unit kerja. 
Pelaksanaan pengelolaan arsip di lingkungan Universitas Padjadjaran belum berjalan secara merata di setiap unit kerja. Arsiparis yang ada belum dipetakan dan tenaga kependidikan yang pernah mengikuti diklat baik ahli maupun terampil belum sepenuhnya mengelola kearsipan, sehingga belum bisa menangani Record Center secara optimal. Arsiparis yang mengelola Record Center secara penuh saat ini baru Record Center I (tingkat Universitas) dan Record Center 2 Fakultas Ilmu Komunikasi, Fakultas Ilmu Budaya, dan Fakultas Ekonomi Bisnis. Pelaksanaan ini baru mulai akhir tahun 2016 atau awal tahun 2017. Kalaupun ada fakultas atau unit kerja lainnya sudah memiliki Record Center 2, arsiparis/pengelola arsipnya masih melaksanakan rangkap tugas.

Berdasarkan pada uraian yang telah dikemukakan, penelitian ini bertujuan untuk mengetahui pemanfaatan arsip dalam pengambilan keputusan strategis oleh para pimpinan. Melalui penelitian ini akan diketahui faktor-faktor yang memengaruhi pemanfaatan arsip dalam proses pengambilan keputusan oleh pihak manajemen tingkat puncak di Fakultas Ilmu Komunikasi Universitas Padjadjaran. Dengan diketahuinya berbagai faktor ini maka pemanfaatan arsip sebagai bahan pertimbangan atau sebagai dasar di dalam menetapkan kebijakan organisai dapat ditingkatkan.

\section{KAJIAN TERDAHULU}

Arsip sebagai sumber informasi dalam pelaksanaan administrasi dan birokrasi. Arsip pada posisi seperti ini berarti sebagai rekaman aktivitas organisasi yang berfungsi sebagai alat bantu ingatan manajemen, penunjang pengambilan keputusan, dan bukti eksistensi organisasi di saat berkoordinasi dan berkomunikasi dengan organisasi lainnya. Hal ini sejalan dengan penelitian yang dilakukan oleh Fathurrahman (2018) berjudul Pentingnya Arsip sebagai Sumber Informasi. Hasil penelitian tersebut menggambarkan bahwa arsip sebagai sumber informasi tidak bersifat tertutup. Hal ini berarti informasi yang terkadung di dalam arsip harus bisa diakses secara terbuka namun penuh rasa tanggung jawab sesuai dengan aturan yang berlaku. Penelitian tersebut menjelaskan pula bahwa "bila di dunia tidak ada arsip berarti dunia tanpa memori, tidak ada kepastian hukum, tanpa kebudayaan, tidak ada perkembangan ilmu sehingga dunia tidak memiliki identitas kolektif" (Fathurrahman, 2018).

Disamping itu, Fathurrahman (2018) dalam penelitiannya mengemukakan bahwa aktivitas organisasi selalu bertitik tolak pada arsip. Aktivitas manajemen mulai dari tahapan perencanaan, pengorganisasian, penggerakan, sampai pada pelaksanaan kontrol pasti bersandar pada informasi yang ada di dalam arsip. Dengan demikian arsip merupakan pilar utama dalam kegiatan pengembangan organisasi. Hal ini memiliki arti pula bahwa setiap proses pengambilan kebijakan dalam setiap tatanan manajemen harus berlandaskan pada informasi yang terkandung dalam arsip organisasi.

Selanjutnya penelitian dengan judul Pemanfaatan arsip Tanah dalam Penyelesaian Kasus Sengketa Tanah oleh Kantor Pertanahan Kota Semarang. Penelitian ini dilaksanakan oleh Chairani, R. N. \& Suliyati, T. (2019). Hasil penelitiannya, Chairani (2019) mengemukakan bahwa arsip sebagai acuan kebijakan organisasi, baik pada masa perencanaan, pelaksanaan, maupun setelah pelaksanaan kegiatan. Hal ini menggambarkan bahwa informasi yang terkandung dalam arsip sangat bernilai dan bermanfaat dalam pergerakan roda organisasi. Selain itu, hasil penelitian Chairani (2019) menggambarkan bahwa proses penyelesaian sengketa tanah harus didasarkan kepada data dan informasi yang akurat, tepat, dan dapat dipertanggungjawabkan kebenarannya. Mengingat sengketa tanah sangat berkaitan dengan hak seseorang atas sebidang tanah. Apabila pada penyelesaian sengketa tanah tanpa dukungan informasi yang akurat, tepat, dan benar maka akan ada pihak yang dirugikan. Pemanfaatan arsip tanah dalam penyelesaian sengketa melalui (a) pencocokan arsip tanah yang ada di Kantor Pertanahan Kota Semarang dengan arsip pihak yang bersengketa, (b) pencocokan dengan kondisi tanah di lapangan.

Penelitian lainnya yang dikaji oleh Puspitarani (2016) tentang pemanfaatan arsip narapidana dalam proses pemberian remisi di Lapas Kelas IIA Wanita Semarang menunjukkan bahwa arsip digunakan sebagai rujukan dan bukti hukum dalam kegiatan pemasyarakatan. Pemanfaatan arsip ini baik dalam kegiatan pembinaan di dalam lapas maupun dalam proses 
pemenuhan hak narapidana dalam memperoleh remisi. Alasan penggunaan arsip narapidana dalam proses pemberian remisi dilakukan sebagai bentuk pemenuhan syarat administratif remisi serta sebagai sumber data dan informasi untuk melengkapi syarat substantif dalam proses pemberian remisi. Arsip yang dijadikan sebagai rujukan dalam pemberian remisi harus memenuhi syarat yakni lengkap dan baik. Hal ini mengandung makna arsip yang dijadikan rujukan harus lengkap seacara fisik dan informasinya utuh.

\section{METODOLOGI PENELITIAN}

Metode yang digunakan dalam penelitian ini yaitu metode kualitatif dengan menggunakan pendekatan studi kasus. Menurut Sugiyono (2015) metode penelitian kualitatif adalah "metode penelitian yang digunakan untuk meneliti pada kondisi obyek yang alamiah, di mana peneliti adalah sebagai instrumen kunci, teknik pengumpulan data dilakukan secara triangulasi (gabungan), analisis data bersifat induktif, dan hasil penelitian kualitatif lebih menekankan makna daripada generalisasi".

Kemudian mengenai pendekatan studi kasus menurut Rahardjo (2017) pendekatan studi kasus berarti kasus yang diangkat menjadi objek penelitian disoroti secara tajam dan mendalam. Selain itu, studi kasus bersifat eksploratif dan deskriptif. Metode ini dipandang efektif karena mampu digunakan untuk mencari motif-motif dibalik fakta sosial yang tampak secara empirik. Penelitian studi kasus memfokuskan pada penelitian dengan cara memerinci data mengenai suatu objek selama kurun waktu tertentu dengan cukup mendalam dan menyeluruh. Selain itu, pertimbangan pemilihan pendekatan ini yaitu sifat data penelitian mampu mempertahankan keutuhan dari objek. Hal ini berarti data yang berkaitan dengan penelitian dipahami sebagai satu kesatuan yang terintegrasi. Dengan demikian pemaparan data akan sesuai dengan fakta di lapangan (Rahardjo, 2017).

Subjek penelitian adalah pimpinan Fakultas Ilmu Komunikasi Universitas Padjadjaran di tingkat manajemen puncak (top-level management) dan arsiparis yang ada di Universitas Padjadjaran. Sumber data penelitian berjumlah lima orang dengan rincian; pimpinan fakultas tiga orang dan arsiparis dua orang. Mereka berperan sebagai informan yang memahami pokok permasalahan yang menjadi objek penelitian yakni proses pengambilan keputusan yang berpijak pada dokumen. Proses pengumpulan data penelitian melalui wawancara, diskusi, observasi, dan studi pustaka. Proses uji validitas dan reliabilitas melalui triangulasi data dan triangulasi sumber. Analisis data secara deskriptif melalui tahapan reduksi, penyajian, dan penarikan kesimpulan \& verifikasi (Rahardjo, 2017). Objek penelitiannya yaitu aktivitas pengambilan keputusan yang dilakukan oleh pimpinan di lingkungan Fakultas Ilmu Komunikasi Unpad dengan didasari pemanfaatan arsip.

\section{HASIL DAN PEMBAHASAN}

\section{Peran Arsip dalam Proses Pengambilan Keputusan}

Arsip sebagai rekaman aktivitas organisasi memiliki peran sebagai pusat ingatan, dasar pertimbangan pengambilan keputusan, bukti keberadaan organisasi, dan sebagai pendukung pelaksanaan manajemen organisasi lainnya. Sebuah organisai tanpa memiliki rekaman aktivitas berorganisasi akan mengalami dan menghadapai banyak masalah. Masalah ini akan muncul baik dalam pelaksanaan kegiatan maupun dalam pengembangan organisasinya, bahkan eksistensi organisasi tersebut akan dipertanyakan. Hal ini sejalan dengan pendapat Okello-Obura (2011). Ia menjelaskan bahwa "Records and archival materials are the indispensable foundation of the accountability process in any democratic society. Without reliable and authentic documentary evidence underpinning all essential accountability processes, government, civil society, and the private sector cannot ensure transparency, guarantee accountability or allow for the exercising of good governance" (Okello-Obura, 2011). Pendapat Okello-Obura (2011) menggambarkan bahwa arsip menjadi pondasi yang sangat kuat untuk membangun akuntabilitas lembaga dalam masyarakat. Sebuah lembaga/pemerintahan dapat menjalankan manajemen/pemerintahan dengan baik bila memiliki dokumen/arsip yang handal dan otentik. Dengan demikian, akuntabilitas sebuah lembaga dapat ditentukan oleh ketersediaan arsip yang baik dan lengkap. Hal senada dikemukakan oleh Mosweu (2018) bahwa "Records and archives legislation is an 
essential component of the wider legislative base of an accountable and effective government" (Mosweu, T. \& Simon, I. 2018).

Hal tersebut sangat disadari oleh pihak manajemen di Fakultas Ilmu Komunikasi Universitas Padjadjaran. Hal ini terlihat dari hasil wawancara dengan pimpinan fakultas bahwa dalam merumuskan suatu keputusan setiap pimpinan di lingkungan Fakultas Ilmu Komunikasi selalu mempertimbangkan berbagai dokumen yang terekam pada arsip. Arsip selalu dijadikan sebagai sumber informasi penting dalam berbagai penyusunan program. Dalam hal ini arsip selalu dimanfaatkan sebagai landasan dalam penyusunan rancangan keputusan dari berbagai aktivitas manajemen. Para pimpinan berpandangan bahwa "pengambilan keputusan bila berlandaskan kepada informasi yang terkandung di dalam arsip akan mengurangi risiko kegagalan dalam penetapan sebuah kebijakan.

Proses pengambilan kebijakan merupakan suatu kegiatan yang berkaitan dengan pemilihan alternatif pemecahan masalah. Pada setiap pilihan harus disertai oleh pertimbangan tentang risiko yang terkandung dalam setiap alternatif. Dengan demikian setiap pengambil keputusan dapat mempertimbangkan alternatif tersebut secara matang dan seksama. Berdasarkan hasil observasi dan wawancara di lapangan, para pimpinan lingkungan Fakultas Ilmu Komunikasi dalam proses pengambilan kebijakan selalu menggunakan arsip dinamis dan statis yang tersimpan di Record Center 2. Hal ini terungkap berdasarkan hasil wawancara dengan pengelola unit arsip. Ia mengemukakan bahwa berbagai pertimbangan yang merujuk dari arsip diperhitungkan dalam proses pengambilan keputusan. Semua itu dilakukan untuk mendapatkan alternatif penyelesaian masalah yang efektif dan efisien.

Kecepatan perolehan arsip dalam pengambilan keputusan sangat diperlukan. Semakin cepat arsip sebagai informasi diperoleh maka akan semakin cepat pula sebuah keputusan dihasilkan. Dari data yang diperoleh di lapangan diketahui bahwa terdapat proses pengambilan keputusan yang menggunakan arsip untuk mendapatkan referensi dan berbagai pilihan alternatif jawaban. Dalam hal ini, arsip digunakan oleh para pimpinan dalam proses pengambilan keputusan yang dilakukan melalui rapat dan diskusi. Informasi yang diberikan oleh sebuah arsip sangat memengaruhi hasil akhir yang akan diputuskan oleh pimpinan fakultas.

Informasi yang terkadung di dalam arsip dijadikan sebagai data pendukung utama untuk proses perumusan masalah, pengembangan alternatif pemecahan masalah, sampai tahap penetapan keputusan untuk pemecahan masalah. Informasi yang ada di dalam arsip terutama arsip dinamis sangat membantu para pimpinan Fakultas Ilmu Komunikasi dalam proses pengambilan keputusan. Para pimpinan Fakultas selalu berkoordinasi dengan para pengelola arsip (arsiparis) untuk selalu siap dalam menyediakan informasi yang dibutuhkan. Mengingat informasi yang terkandung di dalam arsip akan menjadi acuan para pimpinan untuk menentukan sikap dalam menghadapi dan memecahkan masalah.

Berdasarkan kepada gambaran di atas, arsip berperan sebagai pusat informasi dalam setiap tahapan manajemen mulai dari perencanaan program, pelaksanaan, dan evaluasi (Endra, 2017). Hal ini sejalan dengan pandangan Gilliland, A. J., \& McKemmish, S. (2014) tentang arsip. Ia menyatakan bahwa "archives are authoritative sources of information underpinning accountable and transparent administrative actions. They play an essential role in the development of societies by safeguarding and contributing to individual and community memory" (Gilliland, A. J., \& McKemmish, S., 2014). Hal ini menunjukkan bahwa arsip memiliki peran penting dalam setiap tahapan kegiatan yakni perencanaan program, pelaksanaan program, dan evaluasi program. Namun demikian, arsip pun selalu tercipta sejalan dengan aktivitas manjemen. Dalam hal ini, setiap kegiatan manajemen pasti akan tercipta arsip baru yang memiliki peran untuk dasar kebijakan tahap berikutnya. Setiap pemimpin yang akan menetapkan sebuah keputusan akan selalu mempertimbangkan data dan informasi dari aktivitas organisai yang terekam pada arsip. Pemanfaatan arsip sebagai sumber informasi dalam pengambilan keputusan akan mengurangi risiko kesalahan atau kekeliruan dalam penetapan keputusan. Dalam hal ini arsip bisa berperan sebagai data yang dipergunakan untuk dasar pertimbangan, pengetahuan, pemikiran, dan 
penetapan keputusan. Berdasarkan gambaran di atas, peran arsip dalam proses pengambilan keputusan di lingkungan Fakultas Ilmu Komunikasi dapat digambarkan dalam bagan di bawah ini;

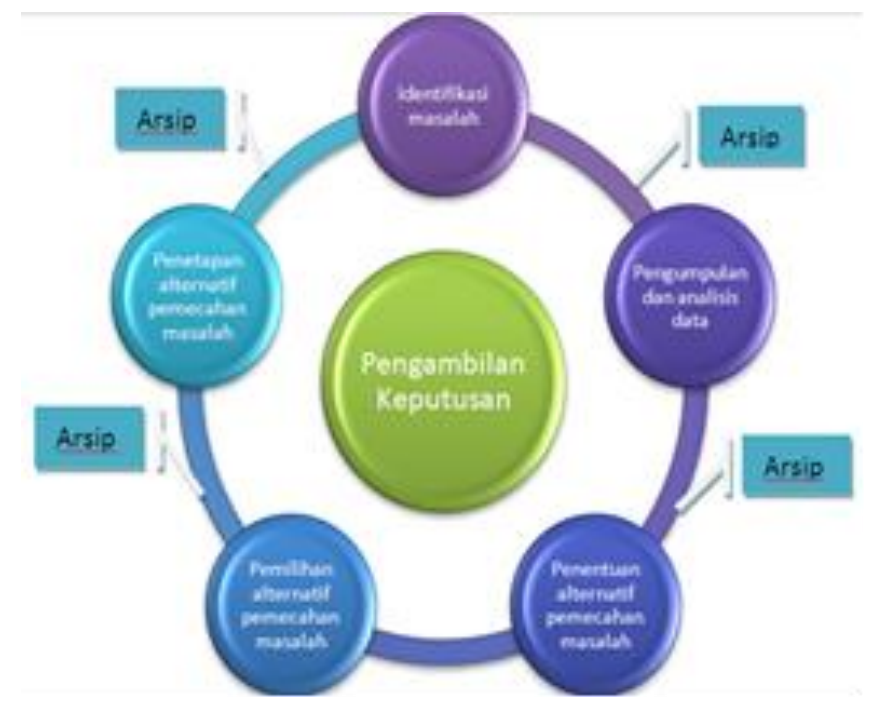

Gambar 1. Peran arsip dalam pengambilan keputusan

Berdasarkan pada gambar di atas, peran arsip dapat diuraikan sebagai berikut;

\section{Identifikasi Masalah}

Identifikasi masalah merupakan proses merumuskan untuk mengenali masalah. Salah satu langkah untuk melakukan identifikasi permasalahan yaitu dengan mengetahui secara jelas masalah yang dihadapi. Proses mengidentifikasi masalah dalam proses pengambilan keputusan di lingkungan Fakultas Ilmu Komunikasi yaitu (1) menentukan permasalahan yang disertai oleh gambaran sifat permasalahan yang dihadapi. (2) Verifikasi merupakan langkah menetapkan permasalahan yang dihadapi. Dalam proses ini dilakukan pengumpulan data sebagai pendalaman terhadap permasalahan yang dihadapi. Pendalaman masalah dilihat dari sektor objek masalah yang relevan, letak penyimpangan yang terjadi, dan sejak kapan penyimpangan tersebut. (3) Mengidentifikasi penyebab timbulnya masalah. (4) Menguji ketepatan penyebab timbulnya masalah (observasi, 2018). Pada tahapan ini dilakukan pengujian berbagai kemungkinan penyebab timbulnya masalah. Proses pengujian dilaksanakan dengan cara pemetaan permasalahan dengan penyebabnya. Melalui proses pemetaan ini dapat diketahui penyebab tersebut betul-betul sebagai penyebab.

Berdasarkan kepada langkah-langkah identifikasi masalah yang telah dilakukan dapat digambarkan bahwa pada tahap identifikasi ini terdapat tiga langkah utama yaitu (1) orientasi yaitu langkah pengenalan masalah, (2) preferensi yakni langkah pengumpulan data, dan (3) definisi yaitu mengklasifikasi dan merumuskan masalah. Pada proses ini peran arsip terdapat pada langkah yang kedua yaitu pada tahap preferensi. Pada tahap ini arsip yang berkaitan dengan permasalahan dijadikan rujukan dan sumber informasi utama.

\section{Pengumpulan dan Analisis Data}

Tujuan pengumpulan data dalam proses ini yaitu untuk mendapatkan gambaran mengenai alternatif penyelesaian masalah yang disertai analisis alternatif terkait risiko yang terkandung di dalam alternatif tersebut. Langkah-langkah pengumpulan data pada tahap ini yaitu (1) menentukan metode pengumpulan data, (2) menentukan skala prioritas terhadap data yang akan dikumpulkan, (3) mengklasifikasi data. Data yang dikumpulkan pada tahap ini harus memenuhi syarat, a. memiliki keterkaitan yang sangat kuat dengan permasalahan, b. ketepatan waktu perolehan data, c. data harus bersifat kredibel, terbatas, akurat, dan tidak saling bertentangan (observasi, 2018). 


\section{Tahap Penentuan Alternatif Pemecahan Masalah}

Pada tahap penentuan alternatif pemecahan masalah tetap memerlukan data dan informasi yang bersumber dari arsip terutama arsip dinamis. Kelengkapan data yang relevan dengan permasalahan akan memengaruhi kualitas alternatif pemecahan masalahnya. Selain melalui penelusuran informasi dari arsip proses pengumpulan data dilakukan pula melalui proses curah pendapat. Metode curah pendapat merupakan cara mendapatkan gagasan dari pihak yang berkepentingan dengan cara menyerap pendapat secara terbuka. Dalam hal ini, setiap orang diberi kebebasan untuk menyampaikan pemikirannya terkait masalah yang sedang dihadapi baik secara lisan maupun tertulis.

Berdasarkan hasil observasi di lapangan, pada tahap penentuan alternatif pemecahan masalah terdapat dua langkah pelaksanaan yaitu pemetaan alternatif dan penilaian alternatif pemecahan masalah. Tahap pemetaan alternatif bertujuan untuk mengatahui risiko dari setiap alternatif dan penilaian bertujuan untuk melihat nilai positif dan negatif dari setiap risiko tersebut. Dengan terpetakannya risiko tersebut para pimpinan mendapat gambaran secara lengkap mengenai semua permasalahan sehingga dapat menentukan pilihan secara tepat mengenai pemecahan masalah (observasi 2018).

\section{Pemilihan Alternatif Pemecahan Masalah}

Penentuan alternatif yang ditetapkan sebagai pemecahan masalah didasarkan kepada kriteria 1. memiliki tingkat risiko paling rendah, 2. efektivitas sumber daya yang dibutuhkan untuk menjalankan alternatif tersebut, 3. waktu yang dibutuhkan untuk melaksanakan alternatif pemecahan masalah. 4. biaya yang dibutuhkan. Hal ini berarti memilih alternatif yang memiliki dampak ekonomi yang paling menguntungkan. Berdasarkan kriteria tersebut pemecahan masalah dapat dilaksanakan secara efektif, praktis, dan tidak terlalu spekulatif.

\section{Penetapan Alternatif Pemecahan Masalah}

Penetapan alternatif pemecahan masalah merupakan pengambilan keputusan dalam pemecahan masalah. Mengambil keputusan merupakan salah satu tahap dalam proses pengambilan keputusan yakni memilih alternatif terbaik. Kelayakan sebuah keputusan terletak pada pelaksanaannya. Oleh karena itu, keputusan yang dikeluarkan harus terdiri dari beberapa unsur yaitu surat keputusan, orang yang menerima/melaksanakan keputusan, perencanaan, distribusi tanggung jawab dan wewenang, skedul waktu dan anggaran belanja.

\section{Pemanfaatan Arsip dalam Pengambilan Keputusan}

Secara prosedural arsip turut dimanfaatkan dalam proses pengambilan keputusan yang dilakukan oleh pimpinan yang ada di tingkat manajemen puncak di Fakultas Ilmu Komunikasi Universitas Padjadjaran. Arsip menjadi hal pertama yang dikumpulkan pada saat proses pengambilan keputusan. Hal tersebut dikarenakan arsip berisikan data dan informasi yang dapat menjadi pertimbangan bagi seorang pimpinan dalam mengambil sebuah keputusan. Hal ini sesuai dengan pendapat dari Sugiarto \& Wahyono (2015). Ia mengatakan bahwa "arsip mempunyai peranan penting dalam proses penyajian informasi bagi pimpinan untuk membuat keputusan dan merumuskan kebijakan".

Namun demikian, ada beberapa hal yang memengaruhi pemanfaatan arsip dalam proses pengambilan keputusan oleh pimpinan yaitu tipe pengambilan keputusan dan dasar pengambilan keputusan. Pertama adalah tipe keputusan yang diambil oleh pimpinan manajemen tingkat puncak di Fakultas Ilmu Komunikasi Universitas Padjadjaran adalah keputusan yang tidak diprogram. Keputusan-keputusan yang diambil tidak didasarkan pada prosedur rutin dan berulang melainkan sebuah keputusan yang sifatnya strategis seperti yang berkaitan dengan program-program baru ataupun masalah-masalah baru yang kompleks dan belum pernah ada sebelumnya. Pernyataan ini diperkuat oleh definisi tipe keputusan tidak diprogram yang dikemukakan oleh Simon (1960) yang dikutip oleh Nugraha (2017) mengatakan bahwa "keputusan tidak akan diprogram jika sifatnya baru dan tidak terstruktur. Oleh karena 
itu, tidak ada prosedur tertentu untuk menanggulangi masalah tersebut, baik karena masalah itu kompleks atau sangat penting".

Selanjutnya jenis dasar pengambilan keputusan yang digunakan, akan memengaruhi pemanfaatan arsip dalam proses pengambilan keputusan yang dilakukan oleh seorang pimpinan. Jenis dasar pengambilan keputusan yang digunakan oleh pimpinan tingkat puncak di Universitas Padjadjaran adalah pengambilan keputusan dengan dasar rasional. Hal ini memiliki makna bahwa pengambilan keputusan didasarkan oleh hal-hal yang bersifat pasti dan rasional seperti pencapaian visi dan misi lembaga. Visi dan misi fakultas merupakan unsur yang harus dicapai sebagai pencapaian visi dan misi universitas dan visi-misi Kementerian Riset, Teknologi, dan Pendidikan Tinggi (Kemenristekdikti). Selain itu, didasarkan pula pada kondisi riel di lapangan serta ketersediaan sumber daya yang dimiliki untuk menjalankan hasil dari keputusan tersebut. Hal ini sesuai dengan definisi dasar pengambilan keputusan rasional yang dikemukakan oleh Mulyadi (2015) yaitu "keputusan yang berkaitan dengan daya guna. Masalahmasalah yang dihadapi merupakan masalah yang memerlukan pemecahan rasional. Keputusan yang dibuat berdasarkan pertimbangan rasional yang lebih bersifat objektif. Seorang pimpinan yang menggunakan dasar pengambilan keputusan rasional akan memanfaatkan arsip dalam proses pengambilan keputusannya. Pihak pimpinan dalam merumuskan keputusan rasional dan objektif dibutuhkan data dan informasi yang aktual dan akurat. Informasi tersebut dapat diperoleh dari arsip-arsip yang tersedia misalnya informasi mengenai visi universitas, visi Kemeristekdikti, dan sumber daya lain yang dimiliki.

Selain tipe dan dasar pengambilan keputusan, ada faktor lain yang memengaruhi seorang pimpinan dalam mengambil sebuah keputusan. Faktor tersebut adalah keberadaan regulasi dan budaya organisasi. Kedua hal akan turut memengaruhi pemanfaatan arsip yang dilakukan oleh seorang pimpinan dalam mengambil keputusan. Pertama, adanya regulasi yang bertolak belakang antara satu aturan dengan aturan lainnya, misalnya ketetapan yang dibuat oleh Kemenristekdikti dengan Kementerian Keuangan. Selanjutnya adalah budaya yang berlaku, yang menyulitkan pimpinan untuk bisa melakukan manajemen perubahan. Kedua faktor ini sesuai dengan pernyataan Pasolong (2015) yang mengemukakan bahwa faktor-faktor yang dapat memengaruhi keputusan yang diambil oleh seorang pimpinan adalah faktor situasi dan faktor kondisi. Faktor situasi adalah keseluruhan faktor dalam keadaan, yang berkaitan satu sama lain, dan secara bersama-sama memancarkan pengaruh terhadap kita beserta apa yang hendak kita buat. Faktor situasi erat kaitannya dengan regulasi yang tidak sinkron, karena dengan situasi seperti ini maka akan memengaruhi seorang pimpinan dalam mengambil keputusan.

Sedangkan faktor kondisi adalah keseluruhan dari faktor yang secara bersama-sama menentukan daya gerak, daya berbuat atau kemampuan kita. Faktor kondisi erat kaitannya dengan kondisi budaya yang berlaku, karena kondisi budaya yang berlaku pada suatu organisasi pun pastinya akan berpengaruh dalam proses pengambilan keputusan yang dilakukan oleh pimpinan. Apabila suatu organisasi sudah mempunyai suatu budaya yang melekat, maka budaya tersebut akan sulit diubah walaupun budaya tersebut sebenarnya budaya yang salah. Salah satu faktor yang memengaruhi pimpinan tingkat manajemen puncak di Universitas Padjadjaran yaitu faktor regulasi yang tidak sinkron, mempunyai kaitan yang erat dengan pemanfaatan arsip dalam proses pengambilan keputusan. Karena regulasi-regulasi yang berlaku tersebut dapat ditemukan di dalam arsip, khususnya arsip yang bernilai administrasi (Sugiarto \& Wahyono, 2015).

Dasar-dasar yang digunakan dan faktor-faktor yang berpengaruh akan memengaruhi gaya pengambilan keputusan yang digunakan oleh seorang pimpinan. Gaya pengambilan keputusan seorang pemimpin akan berpengaruh terhadap pemanfaatan arsip dalam proses pengambilan keputusan yang dilakukan. Berdasarkan hasil pengamatan di lapangan dapat diketahui bahwa gaya pengambilan keputusan yang dianut oleh pimpinan adalah gaya konseptual. Hal ini diketahui karena adanya kecenderungan untuk mengombinasikan antara sifat direktif dan kolektif kolegial yang dilakukan dalam mengambil keputusan. Hal tersebut sesuai dengan gaya pengambilan keputusan konseptual yang dikemukakan oleh Luthans (2006). Ia mengemukakan bahwa pembuat keputusan konseptual mempunyai toleransi tinggi untuk ambiguitas, orang 
yang kuat dan peduli pada lingkungan sosial. Mereka berpandangan luas dalam memecahkan masalah dan suka mempertimbangkan banyak pilihan dan kemungkinan masa mendatang. Pembuat keputusan ini membahas sesuatu dengan orang sebanyak mungkin untuk mendapat sejumlah informasi dan mengandalkan intuisi dalam mengambil keputusan.

Gaya pengambilan keputusan ini merupakan gaya yang paling ideal untuk dimiliki oleh seorang pimpinan, karena bisa menyeimbangkan sifat direktif dan sifat kolektif kolegial dalam mengambil sebuah keputusan. Apabila kedua sifat itu dikombinasikan dengan seimbang, maka keputusan yang diambil pun akan menjadi keputusan yang berkualitas. Pimpinan yang menganut gaya konseptual dalam mengambil keputusan, cenderung akan memanfaatkan arsip dalam proses pengambilan keputusan. Karena sifat kolektif dan kolegial akan dimanfaatkan untuk melakukan pengumpulan data secara bersama-sama dengan seluruh bagian dari unit kerja yang dipimpinnya. Salah satu sumber data dan informasi tersebut adalah arsip-arsip yang dimiliki.

Jenis arsip yang dimanfaatkan oleh pimpinan dalam proses pengambilan keputusan berbeda-beda, sesuai dengan bidang yang dipimpin oleh pimpinan tersebut. Namun berdasarkan hasil penelitian, secara umum jenis arsip yang dimanfaatkan oleh pimpinan tingkat manajemen puncak yang ada di Fakultas Ilmu Komunikasi Universitas Padjadjaran adalah arsiparsip yang bernilai administrasi seperti arsip yang berisi kebijakan-kebijakan pada masa lampau. Hal ini dikarenakan, jenis keputusan yang ditetapkan di tingkat manajemen ini adalah keputusan yang bersifat strategis. Keputusan strategis bersifat tidak diprogram dan mempunyai tujuan jangka panjang. Pernyataan ini diperkuat oleh pernyataan dari Daihani (2001), yang mengatakan bahwa keputusan strategis adalah keputusan untuk menjawab tantangan dan perubahan lingkungan dan biasanya bersifat jangka panjang. Keputusan ini diambil oleh manajemen atas.

Pemanfaatan arsip dalam proses pengambilan keputusan sangat erat hubungannya dengan pengelolaan arsip yang dilakukan dalam sebuah organisasi. Berdasarkan hasil pengamatan diketahui bahwa menurut pimpinan organisasi, pengelolaan arsip yang ada di Universitas Padjadjaran saat ini sudah relatif baik. Namun begitu, tetap ada hal-hal yang masih harus ditingkatkan dan dikembangkan terutama unsur sarana dan sumber daya manusia. Berdasarkan hasil pengamatan, Universitas Padjadjaran sudah memiliki pusat arsip (Record Center 1) di tingkat universitas dan unit arsip (Record Center 2) di tingkat unit kerta dan fakultas. Namun, belum semua unit kerja dan fakultas memiliki unit arsip. Padahal keberadaan Record Center 2 merupakan kewajiban bagi seluruh unit kerja yang ada di Universitas Padjadjaran. Hal tersebut tertuang di dalam Pasal 36 dan 37 Peraturan Rektor Nomor 60 Tahun 2014 tentang Pengelolaan Arsip di lingkungan Universitas Padjadjaran. Pasal tersebut menjelaskan bahwa salah satu sumber daya pendukung dalam pengelolaan arsip adalah Record Center 2. Hal ini pun turut memengaruhi seorang pimpinan dalam proses pengambilan keputusan, karena arsip yang berisikan data dan informasi memegang peranan penting dalam proses pengambilan keputusan. Maka dari itu, dibutuhkan sistem pengelolaan arsip yang optimal agar data dan informasi yang diperlukan dalam proses pengambilan keputusan bisa ditemukan secara cepat dan tepat. Pernyataan ini diperkuat oleh pernyataan dari Sugiarto \& Wahyono (2015), Ia menyatakan bahwa arsip mempunyai peranan penting dalam proses penyajian informasi bagi pimpinan untuk membuat keputusan dan merumuskan kebijakan. Oleh sebab itu, untuk dapat menyajikan informasi yang akurat, tepat waktu (cepat), relevan dan lengkap, haruslah ada sistem dan prosedur kerja yang baik dalam bidang pengelolaan arsip.

Selain sistem kearsipan secara konvensional, pada era teknologi ini setiap instansi harus mulai mengembangkan sistem kearsipan yang berbasis digital. Berdasarkan hasil penelitian di tingkat manajemen puncak diketahui bahwa Universitas Padjadjaran sudah memiliki dua basis aplikasi untuk sistem kearsipan online yaitu E-Office dan SIKD. E-Office merupakan aplikasi surat-menyurat digital dan SIKD (Sistem Informasi Kearsipan Dinamis) merupakan aplikasi keluaran dari Arsip Nasional Republik Indonesia (ANRI). Namun, keduanya belum berjalan secara optimal, karena masih dalam proses pengintegrasian. Pengintegrasian ini dilakukan agar Universitas Padjadjaran memiliki sistem kearsipan digital yang utuh. Saat ini aplikasi E-Office 
hanya diperuntukkan mengirim surat digital secara cepat kepada pihak yang dituju. Namun, sistem kearsipan digital yang disesuaikan dengan kaidah-kaidah kearsipan, Universitas Padjadjaran belum memilikinya. Padahal dengan mengembangkan sistem kearsipan digital, ada banyak keuntungan yang akan didapatkan. Salah satunya yang sangat berhubungan dengan proses pengambilan keputusan adalah kecepatan dalam melakukan temu balik arsip. Hal ini sesuai dengan pernyataan Sukoco (2007), Ia mengatakan bahwa salah satu manfaat manajemen arsip elektronik adalah cepat ditemukan dan bisa memanfaatkan arsip tanpa meninggalkan meja kerja.

Hal lain yang masih harus dikembangkan dalam sistem pengelolaan arsip yang ada di Universitas Padjadjaran adalah pengembangan dari segi sumber daya manusia, khususnya arsiparis. Berdasarkan hasil pengamatan diketahui bahwa sejauh ini masih banyak arsiparis yang memiliki pola pikir konvensional. Padahal penguasaan peranti digital merupakan salah satu kompetensi wajib yang harus dimiliki oleh seorang arsiparis di era teknologi. Hal tersebut dikarenakan teknologi digital yang terus berkembang kedalam berbagai aspek kehidupan berorganisasi tidak terkecuali dalam bidang kearsipan. Hal ini diperkuat oleh pernyataan dari Kallberg (2012). Ia mengatakan arsiparis di era digital harus mampu mengeksploitasi ilmu pengetahuan dengan terus berpikiran terbuka terhadap kemajuan zaman. Untuk mendukung hal tersebut, ada beberapa usaha yang sudah dilakukan seperti menumbuhkan budaya sistem informasi digital yang dilakukan dengan mewajibkan semua pegawai yang ingin mengirimkan surat kepada pimpinan di tingkat ini untuk mengirimkannya dalam bentuk surat digital. Sampai yang sudah menjadi sebuah kebijakan resmi, seperti E-Office dan SIAT (Sistem Informasi Akademik Terpadu).

\section{KESIMPULAN}

Hasil penelitian menunjukkan terdapat empat faktor yang memengaruhi pemanfaatan arsip dalam proses pengambilan keputusan oleh pimpinan yaitu tipe pengambilan keputusan, dasar pengambilan keputusan, keberadaan regulasi, dan budaya organisasi. Pertama tipe keputusan yang diambil oleh pimpinan adalah keputusan yang tidak diprogram. Keputusan-keputusan yang diambil tidak didasarkan pada prosedur rutin dan berulang melainkan sebuah keputusan yang sifatnya strategis seperti yang berkaitan dengan program-program baru ataupun masalahmasalah baru yang kompleks dan belum pernah ada sebelumnya. Selanjutnya jenis dasar pengambilan keputusan yang digunakan, akan memengaruhi pemanfaatan arsip dalam proses pengambilan keputusan yang dilakukan oleh seorang pimpinan. Jenis dasar pengambilan keputusan yang digunakan oleh pimpinan adalah pengambilan keputusan dengan dasar rasional. Hal ini memiliki makna bahwa pengambilan keputusan didasarkan oleh hal-hal yang bersifat pasti dan rasional seperti pencapaian visi dan misi lembaga. Hal ini dilakukan oleh pihak pimpinan karena dalam merumuskan keputusan rasional dan objektif dibutuhkan data dan informasi yang aktual dan akurat. Informasi tersebut dapat diperoleh dari arsip-arsip yang tersedia misalnya informasi mengenai visi universitas, visi Kemeristekdikti, dan sumber daya lain yang dimiliki. Selain tipe dan dasar pengambilan keputusan, ada faktor lain yang memengaruhi seorang pimpinan dalam mengambil sebuah keputusan. Faktor tersebut adalah keberadaan regulasi dan budaya organisasi. Kedua hal ini akan turut memengaruhi pemanfaatan arsip yang dilakukan oleh seorang pimpinan dalam mengambil keputusan. Pertama, adanya regulasi yang bertolak belakang antara satu aturan dengan aturan lainnya, misalnya ketetapan yang dibuat oleh Kemenristekdikti dengan Kementerian Keuangan. Selanjutnya adalah budaya yang berlaku, yang menyulitkan pimpinan untuk bisa melakukan manajemen perubahan.

\section{DAFTAR PUSTAKA}

Chairani, R. N., \& Suliyati, T. (2019). Pemanfaatan arsip Tanah dalam Penyelesaian Kasus Sengketa Tanah oleh Kantor Pertanahan Kota Semarang. Jurnal Ilmu Perpustakaan, 6(3), 691-700.

Okello-Obura, C. (2011). Records and archives legal and policy frameworks in Uganda. Library Philosophy and Practice, 1. 
Dhalimi, A. (2015). Permasalahan gambir (Uncaria gambir L.) di Sumatera Barat dan alternatif pemecahannya. Perspektif, 5(1), 46-59.

Eniyati, S. (2011). Perancangan Sistem Pendukung Pengambilan Keputusan untuk Penerimaan Beasiswa dengan Metode SAW (Simple Additive Weighting). Dinamik, 16(2).

Endra, R. Y., Rizal, U., \& Ariani, F. (2017). E-Arsip Berbasis Image Archives Management Process Model Untuk Meningkatkan Efektifitas Pengelolaan Arsip. EXPLORE, 7(1).

Fathurrahman, M. (2018). Pentingnya Arsip sebagai Sumber Informasi. JIPI (Jurnal Ilmu Perpustakaan dan Informasi), 3(2), 215-225.

Gilliland, A. J., \& McKemmish, S. (2014). The role of participatory archives in furthering human rights, reconciliation and recovery. Atlanti: Review for Modern Archival Theory and Practice, 24.

Indonesia, A. N. R. (2009). Undang-Undang Nomor 43. Tahun 2009, tentang Kearsipan.

Jumiyati, E. (2016). Pengelolaan Arsip Di Pusat Teknologi Bahan Bakar Nuklir. PIN Pengelolaan Instalasi Nuklir, 2(03).

Luthans, F. (2006). Perilaku Organisasi. Yogyakarta: Andi.

Mosweu, T., \& Simon, I. (2018). The implications of the National Archives and Records Services Act on archival practice in Botswana. Journal of the South African Society of Archivists, 51, 70-96.

Mulyadi, D. (2015). Perilaku Organisasi dan Kepemimpinan Pelayanan: Konsep dan Aplikasi Administrasi, Manajemen, dan Organisasi Modern. Bandung: Alfabeta.

Nugraha, T. W. (2017). Analisis Pengambilan Keputusan Dalam Pembelian Pisau Rotary Pada Bisnis Keluarga Pt. Ciptana Wijaya Mandiri (Doctoral dissertation, Unika Soegijapranata Semarang).

Pasolong, H. (2015). Kepemimpinan Birokrasi. Bandung: Alfabeta.

Puspitarani, T., \& Wasisto, J. (2016). Pemanfaatan Arsip Narapidana dalam Proses Pemberian Remisi di Lapas Kelas Iia Wanita Semarang. Jurnal Ilmu Perpustakaan, 5(3), 191-200. https://ejournal3.undip.ac.id/index.php/jip/article/view/15210

Sugiyono, P. (2015). Metode penelitian kombinasi (mixed methods). Bandung: Alfabeta.

Sugiarto, A., \& Wahyono, T. (2015). Manajemen Kearsipan Modern. Yogyakarta: Gava Media.

Rahardjo, M. (2017). Studi kasus dalam penelitian kualitatif: konsep dan prosedurnya. (Thesis, Universitas Maulana Malik Ibrahim Malang) 